\title{
ПОХОДИ РУСІВ У ТАБАРІСТАН У ДРУГІЙ ПОЛОВИНІ IX - НА ПОЧАТКУ Х СТОЛІТЬ: МАРШРУТ І МІСЦЕ У МІЖНАРОДНИХ ВІДНОСИНАХ (ЗА МАТЕРІАЛАМИ ІБН ІСФАНДІЙАРА)
}

\author{
Володимир Кузовков \\ Миколаївський національний університет ім. В.О. Сухомлинського (Миколаїв, Україна) \\ e-mail: kusovkov@ukr.net \\ ORCID: https://orcid.org/0000-0001-7263-6137
}

У статті досліджуються дискусійні питання стосовно обставин перших походів русів на Каспій (між 864-883, 909/910 і 910/911), відомих за свідченнями ібн Ісфандійара, Амулі та Мар'аши. Окрема увага приділяється місцю цих військових акцій у руськохазарських відносинах, їх впливу на міжнародні відносини у регіоні навколо Каспійського моря. Автор розглядає шляхи, якими руси потрапляли до мусульманського світу, і пропонує власну версію маршруту руських контингентів. Відмічається зв'язок розглянутих походів з військовою акцією русів, що відбулась між 913 і 917 рр., відомою за описом альMacydi.

Ключові слова: Русь, походи русів, Хазарія, Табарістан, Каспій, Візантія, БалтійськоВолзький шлях

Зв'язки з сусідніми народами та державами відігравали виняткову роль у ранній історії Київської Русі. Більшість фактів політичної історії Русі у IX-X ст. в уявленні авторів «Повісті минулих літ» пов'язана з відносинами з Візантією. Зв’язки ж з державами і народами Сходу представлені уривчасто. Певною мірою ця історіографічна традиція вплинула і на перші концепції формування Руської держави. По мірі введення у дослідницький обіг джерел східного походження традиційні погляди піддавались ревізії, але ж певні аспекти політико-економічних зв'язків Русі з кочівницьким та ісламським світами потребують подальшого дослідження.

У цьому контексті походи русів на Каспій у IX-X ст. виступають однією з важливих проблем історії міжнародних відносин у Східній Європі. Їх обставини привернули увагу декількох поколінь дослідників (Б.А. Дорн, А.Я. Гаркаві, А.Ю. Якубовський, Н.Я. Половой, В.Ф. Мінорський, М.І. Артамонов, А.П.Новосельцев, Т.М. Калініна, А.Н. Сахаров, П.П. Толочко, В.Я. Петрухін, Д. Шеппард, І.Г. Коновалова)ํ. Особливе місце серед цих військових акцій займають перші каспійські екс-

\footnotetext{
1 Минорский В.Ф. История Ширвана и Дербента Х-ХІ вв. Москва, 1963. 270 с.; Артамонов М.И. История хазар. Ленинград: Государственный Эрмитаж, 1962. 525 с.; Новосельцев А.П. Хазарское государство и его роль в истории Восточной Европы и Кавказа. Москва: Наука, 1990. 264 с.; Сахаров А.Н. Дипломатия Древней Руси. IX - первая половина Х в. Москва: Мысль, 1980. 358 с.; Сахаров А.Н. Дипломатия Святослава. Москва: Международные отношения, 1982. 240 с.; Калинина Т.М. Сведения Ибн Хаукала о походах руси времен Святослава // Калинина Т.М. Проблемы истории Хазарии (по данным восточных источников). Москва: Русский фонд содействия образованию и науке, 2015. С. 235- 247; Калинина T.M. Торговые пути Восточной Европы IX века (по данным Ибн Хордадбеха и Ибн ал-Факиха) // Калинина Т.М. Проблемы истории Хазарии (по данным восточных источников). Москва: Русский фонд содействия образованию и науке, 2015. С. 194-214; Толочко П.П. Древняя Русь. Очерки социально-политической истории. Киев: Наукова думка, 1987.
} 
педиції, згадки про які збереглись у регіональних історичних працях середньовічних іранських авторів XIII-XV ст.: Ібн Ісфандійара, Амулі та Мар'аши. Не дивлячись на значну увагу, яку їм приділили у вищезгаданих дослідженнях, достатнього висвітлення не отримали питання про місце цих військових акцій у руськохазарських відносинах, їх вплив на міжнародні відносини у регіоні навколо Каспійського моря. Остаточно не розв'язано питання про шлях потрапляння русів до регіону.

Походи русів на Каспій повинні були відбуватись у тісному зв'язку з розвитком русько-хазарських відносин. Через Південне Поволжя, де знаходилися політичні центри Хазарії, повинен був проходити маршрут, що приводив русів до Каспійського регіону.

В історіографії зустрічаються різні погляди щодо оцінки ролі Хазарії як транзитної держави для східних військових акцій Русі. Одні дослідники вважали всі східні походи русів заходами, спрямованими проти хазар, і такими, які мають на меті захоплення контролю над шляхами, якими можна було потрапити зі Східної Європи до теренів держав мусульманського світу. Таку точку зору поділяли А.Ю. Якубовський, В.В. Бартольд, А.Н. Насонов, Б.А. Рибаков. М.І. Артамонов вважав, що хазари побоювались міцності Русі й тому пропускали її військові контингенти для грабунку мусульманських володінь на Каспії². А.М. Сахаров відмічав можливу наявність угоди з Хазарією, що забезпечувала шлях русів на Каспій, однак на перше місце ставив реалізацію Руссю союзницьких угод з Візантією. А.П. Новосельцев вважав, що занепад Хазарії можна віднести до 40-х років Х ст., а до цього руси узгоджували свої шляхи до Каспію з хазарською владою4. На думку С. Франкліна та Д. Шеппарда, у 960-х роках хазари являли собою «ослаблого» сусіда, який «все ще заважає русам»5.

Погляд на Хазарський каганат, як на другорядну державу, що з початку Х ст. не могла протистояти русам, не підтверджується свідченнями письмових джерел. Протягом вказаного часу він залишався провідною державою регіону. У середині Х ст. візантійський імператор Константин VII Багрянородний продовжував титулувати його правителя «найшляхетнішим, найвідомішим хаганом Хазарії», додаючи до адресованого йому офіційного листа золоту буллу (печатку) вартістю у три соліда 6 . У той же час правитель Русі отримував буллу вартістю у два соліда, як вожді печенігів та угрів, і більш скромний титул «архонт Росії»7. Аль-

246 с.; Петрухин В.Я. Русь в IX-X веках. От призвания варягов до выбора веры. Москва: ФОРУМ; НЕОЛИТ, 2014. 464 с; Франклин С., Шепард Д. Начало Руси, 750-1200. Санкт-Петербург: Дмитрий Буланин, 2009. 624 с.; Коновалова И.Г. Походы русов на Каспий и русско-хазарские отношения // Восточная Европа в исторической ретроспективе: К 80-летию В.Т. Пашуто. Москва, 1999. С. 111120; Коновалова И.Г. Русы на Каспии в IX - первой половине Х в. (к вопросу о составе участников каспийских походов) // Великий Волжский путь. Материалы Круглого стола «Великий Волжский путь» и Международного научного семинара «Историко-культурное наследие Великого Волжского пути». Казань, 28-29 августа 2000 г. Казань: Изд-во «МастерЛайн», 2001. С. 164-172.

2 Обзор точок зору див.: Сахаров А.Н. Дипломатия древней Руси... С. 186-189.

3 Ibid. C. 198.

${ }^{4}$ Новосельцев А.П. Хазарское государство... С. 214-215, 218-219.

5 Франклин С., Шепард Д. Начало Руси ... С. 234.

${ }^{6}$ Constantine Porfirogenito. De ceremoniis aulae byzantinae libri II. Bonnae, 1828. P. 680-686; Луговой О.М. Политическая карта мира глазами византийского интеллектуала Х века. // Византийская мозаика: Сборник публичных лекций Эллино-византийского лектория при СвятоПантелеимоновском храме. Харьков, 2018. С. 187.

7 Ibidem. 
Масуді відмічав, що цар хазар - єдиний правитель у Східній Європі, хто тримає війська, які отримували жалування8.

Таке бачення політичної ваги Хазарії мали й самі хазарські правителі. Хазарський цар Йосип у своєму листі відмічав наявність хазарської зверхності над більшою частиною східноєвропейського регіону, стверджуючи, що зона впливу каганату доходить до Дніпра9 3 точки зору царя, його особлива місія полягала у захисті мусульманського світу від русів та інших ворогів, яких хазари не допускали на Каспій ${ }^{10}$. Остання ремарка може свідчити про загострення русько-хазарських відносин, або навіть початок збройного конфлікту, з яким пов'язані східний похід Святослава (965р.) та військові акції русів, описані Ібн Хаукалем (бл. 968969 рр.) ${ }^{11}$.

Походи русів на Каспій були складовою процесів розвитку міжнародної торгівлі на теренах від Балтики до Центральної Азії та формування держави Русь. Одним з індикаторів початку цих процесів вважаються поява городища Ладоги (Альдейгьюборг). Виникнення першого поселення тут датують не пізніше 730-х років, а близько 750-х рр. воно перетворюється у провідний центр торгівлі на ВолзькоБалтійському шляху12. Пізніше протягом II половини VIII-IX ст. схожі опорні торгівельні та політичні центри русів (Новгород, Сарське городище, Тимерьово, Гньоздово й інші) виникають вздовж водних шляхів у Східній Європі.

Другим маркером цих процесів $є$ початок обігу східного срібла на вказаних теренах, що відобразилось, зокрема, у знахідках скарбів аббасидських дирхемів ${ }^{13}$. Просування русів у напрямку Каспію відбувалося синхронно з цими процесами.

Проникнення русів у цей регіон пов'язують 3 виникненням БалтійськоВолзького торгівельного шляху. Письмові джерела фіксують використання ними цієї магістралі на відрізку від Ладоги до Волзької Булгарії. Саме тут русів-купців згадує Ібн Фадлан. Волзька Булгарія виступала тим пунктом, де відбувався збут ними своїх товарів в обмін на східне срібло14. Впевнених письмових свідчень про постійні переміщення русів по течії Волги від Волзької Булгарії до Хазарії протягом IX-X ст. ми не зустрічаємо. Ця обставина дозволяє ставити питання про можливість потрапляння русів до Каспію іншим шляхом.

Найбільш рані свідчення про прибуття русів з торговими цілями до Каспію 3 описом їх шляху ми зустрічаємо у працях арабських географів Ібн Хордадбеха та Ібн аль-Факіха. У трактаті Ібн Хордадбеха також міститься розповідь про відправлення халіфом аль-Васіком експедиції Саллама ат-Тарджумана через Хазарію до залізного муру (бл. 842-844 рр.), що захищав світ від народів йаджудж і маджудж (Гога і Магога). За часом ця зацікавленість багдадського двору легендарними

\footnotetext{
8 Минорский В.Ф. История Ширвана и Дербента Х-XI вв. Москва: Восточная литература, 1963. C. 194.

${ }_{9}^{9}$ Коковцов П.К. Еврейско-хазарская переписка. Ленинград: АН СССР, 1932. С. 83, 103.

10 Ibidem.

11 Древняя Русь в свете зарубежных источников: Хрестоматия. Т. III: Восточные источники. Москва, 2009. С. 93-94.

12 Кирпичников Л.Н., Дубов И.В., Лебедев Г.С. Русь и варяги (русско-скандинавские отношения домонгольского времени) // Славяне и скандинавы. Москва: Прогресс, 1986. С. 189-297; Дубов И.В. Великий Волжский путь. Ленинград: ЛГУ, 1990. С. 60-78; Франклин С., Шепард Д. Начало Руси... С. 29.

13 Ibidem. C. 27-28.

14 Ковалевский А.П. Книга Ахмеда ибн-Фадлана о его путешествии на Волгу в 921-922 гг. Харьков: Изд-во Харьковского ун-та, 1956. С. 141-147.
} 
північними племенами збігається з часами початку активності русів у регіоні15. В ці ж часи про русів дізнаються і в Константинополі, а згодом і при дворі франкського імператора Людовіка I Благочестивого в Інгельхаймі завдяки їх посольству (839 р.) $)^{16}$.

Ібн Хордадбех приділяє окрему главу торгівельній діяльності русів, в якій надає опис маршруту їх пересування. Вважається, що праця цього арабського географа була закінчена близько 880-х років ${ }^{17}$, але ж свідчення про русів датують 840 -ми роками, або навіть першою третиною IX ст.18 Згідно зі свідченнями Ібн Хордадбеха, руси відправляються вести торгівлю або у Візантію, або у халіфат. За Н. Веліхановою, переклад опису шляху русів до мусульманського світу виглядає наступним чином: «Якщо вони відправляються по Танісу - річці слов'ян, то проїжджають мимо Хамліджа, міста хазар. Їх володар (сахіб) також збирає з них десятину. Потім вони відправляються по морю Джурджан і висаджуються на будь-якому березі... Іноді вони везуть свої товари від Джурджана до Багдаду на верблюдах. Перекладачами [для] них є слов'янські слуги-євнухи (хадам). Вони стверджують, що вони християни і платять подушний податок (джиз'ю)» ${ }^{19}$. Певні відмінності має переклад цього тексту, зроблений Т.М. Калініною: «А також йдуть по [Та?]нісу, річці слов'ян, входять до Хамліджу, міста хазар, і бере з них десятину їх володар. Потім відправляються до моря Джурджана і виходять на будь-якому уподобаному березі... Іноді везуть свої товари із Джурджана до Багдаду, і переводять ним слов'янські слуги, і кажуть вони, що вони - християни, і платять джиз'ю20.

Ключовими пунктами маршруту русів, відомими Ібн Хордадбеху, у цьому фрагменті виступають Таніс, або [Та?]ніс, «ріка слов'ян», Хамлідж, Каспійське море і Багдад. Дискусії серед дослідників викликала ідентифікація перших двох пунктів. Із повідомлення Ібн Хордадбеха можна зробити висновок, що Хамлідж розташовувався у пониззі Волги і часто співвідноситься зі столицею та резиденцією правителя хазар Ітілем²1. Ця локалізація підтверджується іншим пасажем Ібн Хордадбеха, згідно з яким з Джурджана до Хамліджа вісім днів шляху Каспійським морем й останній розташований у гирлі ріки, що «витікає $з$ країни слов'ян (асСакаліба) і впадає в море Джурджан»22.

«Таніс», або «[Та?]ніс, ріка слов'ян» часто інтерпретується, як гідронім, похід-

15 Ибн Хордадбех. Книга путей и стран. Баку: Элм, 1986. С. 130. Див. також: Кузовков В.В. Хозарський каганат і мусульманський світ у IX ст. // Науковий вісник Миколаївського національного університету імені В.О. Сухомлинського: Збірник наукових праць. Вип. 4.33: Історичні науки. Миколаїв: МНУ, 2013. С. 185.

16 Древняя Русь в свете зарубежных источников: Хрестоматия. T. IV: Западноевропейские источники. Москва: Русский Фонд Содействия Образованию и Науке, 2010. С. 19.

17 Древняя Русь в свете зарубежных источников. Хрестоматия. Т. III... С. 24.

18 Калинина Т.М. Торговые пути Восточной Европы... С. 208; Древняя Русь в свете зарубежных источников. Под ред. Е.А. Мельниковой. Москва: Логос, 2003. С. 205.

19 Ибн Хордадбех. Книга путей и стран. Баку: Элм, 1986. С. 124.

20 Древняя Русь в свете зарубежных источников. Т. ІІІ... С. 31.

21 Артамонов М.И. История хазар. Ленинград: Государственный Эрмитаж, 1962. С. 388; Новосельцев А.П. Хазарское государство... С. 129-130.

Сучасний джерелознавчий аналіз згадок Хамліджа та історіографію див.: Калинина Т.М., Флёров В.С., Петрухин В.Я. Хазария в кросскультурном пространстве: историческая география, крепостная архитектура, выбор веры. Москва: Рукописные памятники Древней Руси, 2014. С. 42-43.

22 Цит. за: Ибн Хордадбех. Книга путей и стран... С. 109. Можна порівняти з: Древняя Русь в свете зарубежных источников. Т. III... С. 29. 
ний від античної назви р. Дон - Танаїс23. Н. Веліханова також пропонує форму «Донус»24. За їі перекладом «Таніс - річка слов'ян» виступає вихідним пунктом шляху русів, яким вони пізніше досягають Хамліджа25. Т.М. Калініна вважає, що не можна впевнено співвідносити «ріку слов'ян» з Доном, оскільки за текстом Ібн Хордадбеха по ній руси потрапляють до Хамліджа, розташованого у гирлі р. Волга. Це дозволяє співвіднести «ріку слов'ян» і з Волгою. При цьому дослідниця вважає не коректним спроби заміни «[Та?]ніс» на Ітіль. Посилаючись на В.Ф. Мінорського, Т.М. Калініна відмічає, що арабське дієслово «входять» (марру) має ще значення «переправляються». Подібний переклад, на думку першого дослідника, дозволяє вважати, що мова йде про переправу «з Дону до Волги»26.

Отже, свідчення Ібн Хордадбеха дозволяють говорити, що торгівельні подорожі русів до мусульманського світу близько 800-840-х років проходили через хазарські володіння у Нижньому Поволжі та Каспійське море. Через слабку обізнаність Ібн Хордадбеха стосовно географії річок Східної Європи, ми не можемо впевнено казати про шляхи потрапляння русів до Хазарії27. Однак, зі значною долею вірогідності, враховуючи вищенаведені варіанти читання тексту джерела, ми можемо припустити, що мова йде про шлях, який проходив течією Дону до волоку до Волги, а далі Волгою через Хамлідж до Каспію.

Ситуацію, що склалась у другій половині IX ст., описує Ібн аль-Факіх, взявши за основу попередні свідчення Ібн Хордадбеха ${ }^{28}$. Згідно з Ібн аль-Факіхом, кінцевим пунктом шляху русів у халіфаті вже був не Багдад, а Рей. Певних змін зазнав і їх маршрут. За Ібн аль-Факіхом руси відправлялись з товаром наступним шляхом: візантійські володіння (Константинополь, або Крим) - Самкарш юдеїв (Таматарха) - землі слов'ян або море слов'ян (Азовське море?) - річка слов'ян (Дон) - протока хазар (Волга з Хамліджем) - море Хорасанське (Каспійське море). Свідчення Ібн аль-Факіха дозволяють припускати функціонування маршруту, яким руси потрапляли до Хазарії не з Середньої Волги, а з Чорного моря.

Вихідним пунктом, звідки руси потрапляли до Каспію, могло бути Середнє Подніпров'я, де на початку Х ст., а, можливо, й раніше, виникає політичний центр у Києві ${ }^{29}$. Поява його пов'язана з виникненням шляху «з варяг у греки», що від-

23 Ibid. C. 31; Ибн Хордадбех. Книга путей и стран... С. 124.

24 Ibid. C. 332.

25 «Якщо вони відправляються по Танісу - річці слов'ян, то проїжджають повз Хамліджа, міста хазар». Див.: Ибн Хордадбех. Книга путей и стран... С. 124.

26 Калинина Т.М. Торговые пути Восточной Европы... С. 206.

27 Ibidem.

28 Древняя Русь в свете зарубежных источников. Т. III... С. 35. Порівняльний аналіз свідчень Ібн Хордадбеха та Ібн аль-Факіха див.: Калинина Т.М. Торговые пути Восточной Европы... С. 207-208.

29 Питання про час виникнення Києва та перетворення його на політичний центр Русі залишається дискусійним. На думку Л. Войтовича, вихідці зі Скандинавії утвердилися у Середньому Подніпров'ї, зокрема у Києві, ще у першій половині IX ст. (Войтович Л. Загадки вікінгів: Ладога і Пліснеськ. Продовження дискусії на межі XX-XXI століть // Україна: культурна спадщина, національна свідомість, державність. 2011. Вип. 20. С. 166).

С. Франклін і Д. Шеппард відносять цю подію близько кінця 930-х років (Франклин С., Шепард Д. Начало Руси... С. 184, 197 ).

Комар відносить виникнення укріплень Старокиївського городища до межі IX-X ст., а до кінця IX ст. - виникнення Подолу та зростання населення завдяки прибулим групам (Комар А.В. Киев и Правобережное Поднепровье // Русь в IX-X веках: археологическая панорама. Москва-Вологда: Древности Севера, 2012. С. 319-320).

О.П. Толочко, посилаючись на археологічні джерела, відносить виникнення Києва, як центру 
крив для русів Чорне море і доступ до Візантії. Аргументом на користь цього є те, що реалії, описані Ібн аль-Факіхом, співпадають у часі з правлінням літописного князя Аскольда $(860 / 862-882)^{30}, 3$ яким пов'язують активізацію руськовізантійських зв'язків через Чорне море) ${ }^{31}$. До цього часу відноситься і першій відомий похід русів на Каспій (близько 864-883 рр.) ${ }^{32}$.

Згадки про перші походи русів на Каспій збереглись в «Історії Табарістану» Ібн Ісфандійара, написаній у XIII ст. 33 Крім вищезгаданого походу, цей автор повідомляє нам про напади русів у 909/910 р. і 910/911 р. Згідно з Ібн Ісфандійаром руси атакували м. Абасгун у Табарістані, але їх напад відбив місцевий правитель Хасан б. Зайд. Оскільки час походу не вказується, то його прийнято датувати періодом його правління (864-883 рр.).

Питання про цілі й обставини перших походів підіймались у дослідженнях. Крім звичайного грабіжництва, висловлювались припущення про зв'язок експедицій з дипломатичними угодами, укладеними Руссю 3 іншими державами. А.М. Сахаров вважав, що перший похід русів на Каспії реалізовував союзницьку русько-візантійську угоду. Таким чином руси завдавали удару по володінням халіфату, з яким Візантія вела тривали війни ${ }^{34}$.

Однак розглядати перший похід у контексті русько-візантійських відносин заважає той факт, що противником русів виступав шиїтський правитель династії Зайдідів (гілка Алідів) 35 . У 867 р. Хасан б. Зайд розбив армію емірів Тахірідів, що представляли владу халіфів Аббасидів в Ірані 36, у 873/874 pp. вів боротьбу проти військ еміра Саффаріда Якуба б. Лайса, у таборі якого були присутніми посли багдадського халіфа аль-Мутаміда ${ }^{37}$. Протягом свого правління Хасан б. Зайд залишався ворогом сунітських халіфів Багдаду. Останні вважали за можливе використати проти його сил у Табарістані навіть Саффарідів, які самі часто поводили себе нелояльно по відношенню до халіфської влади.

Ареал політичної діяльності Хасана б. Зайда обмежувався теренами Північного Ірану і його війська воювали з халіфами Аббасідами та їх союзниками. Існуючи джерела не дозволяють стверджувати про зв'язки держави Хасана б. Зайда з Візантією. 3 огляду на характер його політики, він скоріш міг розглядатись, як потенційний союзник імперії у регіоні, як хурраміти Бабека у 830-х роках.

дальньої торгівлі, до кінця IX ст. (Толочко А.П. Очерки начальной Руси. Киев-Санкт-Петербург: Лаурус, 2015. С. 164).

К. Цукерман, незгодний з літописною хронологією, відносить початок правління князя Олега до першого десятиліття Х ст., пересуваючи і часи утвердження русів у Середньому Подніпров'ї на цей час (Цукерман К. Перестройка древнейшей русской истории // У истоков русской государственности. К 30 -летию археологического изучения Новгородского Рюрикова городища и Новгородской обласной археологической экспедиции. Санкт-Петербург, 2007. С. 351).

30 Лихачев Д.С. (сост.). Повесть временных лет. Москва: АН СССР, 1950. Ч. 1. С. 18-20, 214-217.

31 Ибн Хордадбех. Книга путей и стран... С. 124.

32 Древняя Русь в свете зарубежных источников. Т. ІІІ... С. 164-166.

33 Ibid. C. 164-166.

34 Сахаров А.Н. Дипломатия древней Руси... С. 214. С. Франклін і Д. Шеппард відмітили хронологічний зв'язок між походом русів на Константинополь у 860 p. і експедицією на Каспій. Див.: Франклин С., Шепард Д. Начало Руси... С. 97-98.

35 Про захват влади у Табарістані Хасаном б. Зайдом див.: Ал-Масуди. Золотые копи и россыпи самоцветов. Москва: Наталис, 2002. С. 356-357.

36 Ibid. C. 378.

37 Ibid. C. 402. 
Більш важливими, у контексті першої експедиції русів на Каспій, виглядають русько-хазарські відносини. У другий половині IX ст. потрапити у цей регіон руси могли тільки через територію Хазарії, що дозволяє припустити існування у них домовленостей з представниками хазарської влади. На думку І.Г. Коновалової, прихильники Хасана б. Зайда оволоділи Гурганом, Рей і Казвін - важливими пунктами на торгівельних шляхах, чим негативно вплинули на економічні зв'язки між Східною Європою та мусульманським світом ${ }^{38}$.

До наслідків політичної нестабільності на південному узбережжі Каспію можливо слід віднести і «першу велику кризу срібла у Східній Європі». Т. Нунен позначав їі хронологічні межі 870-900 роками, вважаючи, що вона призвела до зменшення обсягів постачання срібних дирхемів на теренах від Ітіля (Поволжя) до Бірки (Швеція) ${ }^{39}$.

Військові експедиції русів на Каспій у 909/910 і 910/911 рр. співпали з загостренням відносин Хазарії з мусульманськими правителями Ширвану та Дербенту. Між 901 і 916 рр. відбулося декілька військових зіткнень, унаслідок яких правителі згаданих мусульманських держав потрапляли у полон до хазар та їх союзників ${ }^{40}$. Однак Ібн Ісфандійар, автор свідчень про ці експедиції, розповідає про дії русів на південному узбережжі Каспія, де їх противниками були намісники емірів Саманідів, які на початку Х ст. взяли під контроль цей регіон. Тільки на зворотному шляху русів, що уціліли після боїв на березі, атакували морські сили правителя Ширвану41.

Отже, нестача джерельних свідчень не дозволяє нам встановити багато деталей подій, що пов'язані з експедиціями 909/910 і 910/911 pр. 3 великою вірогідністю можна стверджувати про існування домовленості русів з хазарами, через володіння яких вони повинні були проходити. Але у Ібн Ісфандійара дії русів проти ширваншаха $є$ другорядними, а головним противником виступають середньоазійські Саманіди. Місцева «Історія Дербенту» не згадує про дії русів на Каспї, що заважає зробити конкретні висновки про можливу взаємодію русів і хазар у регіоні в ці роки. Прямі свідчення про характер відносин хазар з Саманідами у 909-911 рр. у письмових джерелах відсутні, що дозволяє лише висувати здогадки: чи були середньоазійські еміри у союзі з Ширваном і Дербентом проти каганату?

Певним індикатором міжнародних відносин у регіоні можуть виглядати зв'язки Хазарії та Саманідів з огузами. Наприкінці IX ст. хазари й огузи разом діяли в союзі проти печенігів ${ }^{42}$. Погіршення відносин між хазарами й огузами відбувається не пізніше 920-х років, що фіксує Ібн Фадлан ${ }^{43}$. Ворожість відносин між Саманідами й оточуючими їх володіння тюрками-язичниками фіксується джерелами з IX ст. На межі IX-X ст. емір Саманідів Ісмаїл (892-907) вів постійні військові

\footnotetext{
38 Коновалова И.Г. Походы русов на Каспий... С. 111-120.

39 Франклин С., Шепард Д. Начало Руси... С. 103-105.

40 Минорский В.Ф. История Ширвана и Дербента Х-ХІ вв. Москва: Восточная литература, 1963. С. 47-48, 65

41 Древняя Русь в свете зарубежных источников... Т. III. С. 164-165; Алиев С.М. О датировке набега русов, упомянутых ибн Исфандийаром и Амоли // Восточные источники по истории народов Юго-Восточной и Центральной Европы. Москва: Наука, 1969. С. 316-321.

42 Константин Багрянородный. Об управлении империей. Москва: Наука, 1989. С. 154-155; Новосельцев А.П. Хазарское государство... С. 225.

43 Ковалевский А.П. Книга Ахмеда ибн-Фадлана о его путешествии на Волгу в 921-922 гг. Харьков: Изд-во Харьковского ун-та, 1956. С. 129.
} 
дії з кочовиками вздовж своїх кордонів, а про пізніше становище емірату Саманідів географ аль-Істахрі писав: «Весь кордон Мавераннахру - місце військових дій: від Хорезму до околиць Ісфіджаба - з тюрками-огузами, а від Ісфіджаба до віддалених міст Фергани - з тюрками-карлуками»44. Отже, наприкінці IX ст. огузи ворогували з мусульманами Мавераннахру і були союзниками хазар, але до 920-х років навпаки опинились у ворожому оточенні з боку і хазар, і мусульман. Але ж подібна схема виглядає доволі спрощеною і не знаходить прямих підтверджень у письмових джерелах.

3 нападами русів на Табарістан у 909/910 і 910/911 рр. пов'язаний похід русів на Каспій, що відбувся між 913 і 917 рр. і відомий за свідченнями аль-Масуді45. Його політичні обставини розібрані в іншій публікації46. Тут слід відмітити його у зв'язку з питанням про маршрут проникнення руських військових контингентів на Каспій. Аль-Масуді відмічав, що руси потрапили до Каспію з Чорного моря (моря Бунтус). Цей шлях співвідноситься з тим, про який повідомляє Ібн аль-Факіх ${ }^{4}$.

Отже, розгляд свідчень історичних джерел дозволяє стверджувати, що руські військові акції, описані Ібн Ісфандійаром, а також пізніми авторами - Амулі та Мар'аши, відбувались у зв'язку з політикою Хазарії у регіоні. На межі IX-X ст. Хазарський каганат залишався провідним державним утворенням Східної Європи, з могутністю якого повинні були рахуватись Візантія та Арабський халіфат. Можливість потрапити на Каспій для русів залежала від позиції правителів Ітилю. Прямий зв'язок цих акцій з русько-візантійськими угодами не простежується і супротивниками русів у регіоні частіше виступали мусульманські правителі, які не знаходились у прямій конфронтації з Константинополем, або могли виступити в якості потенційних союзників для Візантії. Перший похід русів був спрямований проти Хасана б. Зайда, шиїтського правителя Табарістана. Останній діяв проти халіфів Багдада, захопивши терарії, через які проходили шляхи русів-купців. Експедиції 909/910 і 910/911 рр. призвели до зіткнень русів з силами емірів Саманідів у Табарістані. Ми не можемо впевнено говорити про те, чи мали ці напади політичне підгрунтя, але вони припинились після врегулювання відносин між Хазарією та середньоазійськими емірами. 3 великою вірогідністю можна стверджувати, що руси потрапляли до Каспію з Чорного моря, проходячи через Азовське море, Дон і Волгу, а вихідним пунктом для цих походів слід вважати Середнє Подніпров'я, де не пізніше початку Х ст. з’ явився центр князівської влади у Києві.

\section{REFERENCES}

Aliev, S.M. (1969). O datirovke nabegov rusov, upomianutykh ibn Isfandiiarom i Amoli [On the dating of the raid of the Rus mentioned by Ibn Isfandiyar and Amoli]. In Vostochnye istochniki po istorii narodov Yugo-Vostochnoi i Tsentralnoi Evropy, (Vol. II, pp. 316-321). Moskva: Nauka [in Russian].

Artamonov, M.I. (1962). Istoriia khazar [The history of Khazars]. Leningrad [in Russian].

Dorn, B.A. (1875). O pokhodakh drevnikh russkikh v Tabaristan [About the campaigns of the ancient Russians to Tabaristan]. Sankt-Petersburg [in Russian].

\footnotetext{
44 Цит. за: Кляшторный С.Г., Савинов Д.Г. Степные империи Древней Евразии. Санкт-Петербург: Филологический факультет СПбГУ, 2005. С. 118.

45 Минорский В.Ф. История Ширвана и Дербента X-XI вв. С. 196-197, 198-201; Древняя Русь в свете зарубежных источников. Т. ІІІ... С. 114-116.

46 Кузовков В.В. Похід русів на Каспій і русько-хазарська угода у контексті міжнародних відносин першої чверті Х століття // Colloquia Russica. Series I, Vol. 10: Diplomacy of Medieval Rus' of the $10^{\text {th- }}$ $16^{\text {th }}$ сс. (у друці).

47 Древняя Русь в свете зарубежных источников. Т. III... С. 35.
} 
Dubov, I.V. (1990). Velikii Volzhskii put [Great Volga route]. Leningrad: LGU [in Russian].

Franklin, S. \& Shepard, D. (2009]. Nachalo Rusi, 750-1200 [The Emergence of Rus: 750-1200]. SanktPetersburg: Dmitrii Bulanin [in Russian].

Kalinina, T.M. (2015). Problemy istorii Khazarii (po dannym vostochnykh istochnikov) [Problems of the history of Khazaria (according to eastern sources)]. Moskva: Russkii fond sodeistviia obrazovaniiu i nauke [in Russian].

Kalinina, T.M., Flyorov, V.S. \& Petrukhin, V.Y. (2014). Khazariia v krosskulturnom prostranstve: istoricheskaia geografiia, krepostnaia arkhitektura, vybor very [Khazaria in Cross-cultural Space: Historical Geography, Fortress Architecture, Choice of Faith]. Moskva: Rukopisnye pamiatniki Drevnei Rusi [in Russian].

Kirpichnikov, L.N., Dubov, I.V. \& Lebedev, G.S. (1986). Rus i variagi (russko-skandinavskie otnosheniia domongolskogo vremeni) [Russia and the Varangians (Russian-Scandinavian relations of the preMongol period)]. Moskva: Progress [in Russian].

Kliashtornyi, S.G. \& Savinov, D.G. (2005). Stepnye imperii Drevnei Evrazii [Steppe empires of Ancient Eurasia]. Sankt-Petersburg: Filologicheskii fakultet SPbGU [in Russian].

Komar, A.V. (2012). Kiev i Pravoberezhnoe Podneprovie [Kiev and the Right Bank Dnieper]. In Rus v IX$X$ vekakh: arkheologicheskaia panorama. Moskva-Vologda, pp. 300-332 [in Russian].

Konovalova, I.G. (2001). Rusy na Kaspii v IX - pervoi polovine X v. (k voprosu o sostave uchastnikov kaspiiskikh pokhodov) [Rus in the Caspian Sea in the 9th - first half of the $10^{\text {th }}$ century (to the question of the consist of the participants in the Caspian campaigns)]. Proceedings of the Conference: «Velikii Volzhskii put». Kazan: MasterLain, pp. 164-172 [in Russian].

Konovalova, I.G. (1999). Pokhody rusov na Kaspii i russko-khazarskie otnosheniia [Rus campaigns to the Caspian Sea and Russian-Khazar relations]. In Vostochnaia Evropa v istoricheskoi retrospective. Moskva, pp. 111-120 [in Russian].

Kuzovkov, V.V. (2013). Khozarskyi kahanat i musulmanskyi svit u IX st. [Khazar Khaganate and the World of Islam in the 9th century]. Naukovyi visnyk Mykolaivskoho natsionalnoho universytetu imeni V.O. Sukhomlynskoho: Istorychni nauky, 4.33, 182-188 [in Ukrainian].

Kuzovkov, V.V. (2020). Pokhid rusiv na Kaspii i rusko-khazarska ukhoda u konteksti mizhnarodnykh vidnosyn pershoi chverti X stolittia [Rus' march on the Caspian Sea and the Russo-Khazar agreement in the context of international relations of the first quarter of the tenth century]. Colloquia Russica. Series I, Vol. 10: Diplomacy of Medieval Rus' of the 10 $10^{\text {th }}-16^{\text {th }}$ cc. (in publ.) [in Ukrainian].

Lebedev, G.S. (2005). Epokha vikingov v Severnoi Evrope i na Rusi [The era of the Vikings in Northern Europe and in Rus']. Sankt-Petersburg: Evraziia [in Russian].

Likhachev, D.S. (Comp.) (1950). Povest vremennykh let [The Tale of Bygone Years]. Moskva: AN SSSR [in Russian].

Lugovoi, O.M. (2018). Politicheskaia karta mira glazami vizantiiskogo intelektuala X veka [The political map of the world through the eyes of the Byzantine intellectual of the $10^{\text {th }}$ century]. Vizantiiskaia mozaika Sbornik publichnykh lektsii Ellino-vizantiiskogo lektoriia pri Sviato-Panteleimonovskom khrame. Kharkov, pp. 159-190 [in Russian].

Melnikova, E.A. (2003). Drevniaia Rus v svete zarubezhnykh istochnikov [Ancient Russia in the light of foreign sources]. Moskva: Logos [in Russian].

Mets, A. (1973). Musulmanskii renessans [Muslim renaissance]. Moskva [in Russian].

Miuller, A. (2004). Istoriia islama. Ot musulmanskoi Persii do padeniia musulmanskoi Ispanii [History of Islam: From Muslim Persia to the Fall of Muslim Spain]. Moskva: Astrel-ACT [in Russian].

Novoseltsev, A.P. (1990). Khazarskoe gosudarstvo i ego rol v istorii Vostochnoi Evropy i Kavkaza [Khazar state and its role in the history of Eastern Europe and the Caucasus]. Moskva: Nauka [in Russian].

Petrukhin, V.Y. (2014). Rus $v$ IX-X vekakh: Ot prizvaniia variagov do vybora very [Rus in the $9^{\text {th }}-10^{\text {th }}$ centuries. From varangians invitation to the choice of faith]. Moskva: Forum Neolit [in Russian].

Sakharov, A.N. (1980). Diplomatiia drevnei Rusi. IX - pervaia polovina X v. [Diplomacy of Ancient Rus. $9^{\text {th }}$ - first half of the $10^{\text {th }}$ century]. Moskva: Mysl [in Russian].

Tolochko, A.P. (2015). Ocherki nachalnoi Rusi [Essays on early Rus]. Kiev-Sankt-Petersburg: Laurus [in Russian].

Tolochko, P.P. (1987). Drevniaia Rus: Ocherki sotsialno-politicheskoi istorii [Ancient Rus: Essays on socio-political history]. Kiev: Naukova dumka [in Russian].

Voitovych, L. (2011). Zahadky vikinhiv: Ladoha i Plisnesk. Prodovzhennia dyskusii na mezhi XX-XXI stolit [Riddles of Vikings: Ladoga and Plisnesk. Continuation of the discussion at the boundaries of the XX-XXI centuries]. Ukraina: kulturna spadshchyna, natsionalna svidomist, derzhavnist, 20, 142-188 [in Ukrainian]. 
Zuckerman, K. (2007). Perestroika drevneishei russkoi istorii [(Re-)structuring early Russian history]. $U$ istokov russkoi gosudarstvennosti. K 30-letiiu arkheologicheskogo izucheniia Novgorodskogo Riurikova gorodishcha i Novgorodskoi oblasnoi arkheologicheskoi ekspeditsii. Sankt-Petersburg, pp. 343-351 [in Russian].

\section{Volodymyr Kuzovkov}

(Mykolaiv National University named after V. Sukhomlinsky, Mykolaiv, Ukraine) e-mail: kusovkov@ukr.net

ORCID: https://orcid.org/0000-0001-7263-6137

\section{Rus Campaigns in Tabaristan in the Second Half of the $9^{\text {th }}-$ Early $10^{\text {th }}$ Century: Route and Place in International Relations (on Materials of Ibn Isfandiyār)}

The route and place in international relations of the Rus campaigns in Tabaristan, which took place in the second half of the $9^{\text {th }}-$ early $10^{\text {th }}$ century, are studied in the paper. Attention is also paid to the issue of the place of those military actions in Rus-Khazars relationships.

During the studied period, the Khazar Khaganate remained the leading state in the region. The getting of the Rus to the Caspian Sea was possible only with the consent of the rulers of the Khazar Khaganate.

The passage of the Rus into this region is associated with the emergence of the Volga trade route. However, they used this way only from Ladoga to Volga Bulgaria. No reliable sources are telling about the Rus moving along the Volga between Volga Bulgaria and Khazaria during the $9^{\text {th }}-10^{\text {th }}$ centuries.

It can be said with high probability that the Rus came to the Caspian Sea from the Black Sea, over the Sea of Azov, the Don, and the Volga, and the starting point for mentioned campaigns should be considered the Middle Dnipro region, where not later than the early $10^{\text {th }}$ century the center of princely power appeared in Kyiv.

There is no direct link between those actions and the Rus-Byzantine treaties, and the enemies of the Rus in the region were more often Muslim rulers who were not in direct confrontation with Constantinople or could act as potential allies of the Byzantine Empire. The first campaign of the Rus was directed against Hasan ibn Zayd, the Shiite ruler of Tabaristan. The latter acted against the caliphs of Baghdad, having captured terraria through which the paths of Rus merchants passed. Expeditions of 909/910 and 910/911 years caused the clashes between the Rus and the forces of the Samanid emirs in Tabaristan. We cannot say for sure whether those attacks were politically motivated, but they were stopped after mending differences between Khazaria and the Central Asian emirs.

Keywords: Rus, Rus campaigns, Khazaria, Tabaristan, Caspian Sea, Byzantium, VolgaBaltic Waterway 